\title{
Muslim Students Learning L2 and FL in Minority Primary Schools in Thrace: Relational Instances of Tri/Bilingualism
}

\author{
Maria Dimasi $^{1} \&$ Stella Theologou ${ }^{2}$ \\ ${ }^{1}$ Department of Languages, Literature and Culture of the Black Sea Countries, Democritus University of Thrace, \\ Komotini, Greece \\ ${ }^{2}$ Department of Languages, Literature and Culture of the Black Sea Countries, Democritus University of Thrace, \\ Komotini, Greece \\ Correspondence: Stella Theologou, Department of Languages, Literature and Culture of the Black Sea Countries, \\ Democritus University of Thrace, P. Tsaldari, 1, 6100, Komotini, Greece. E-mail: \\ stella_theologou@hotmail.com
}

Received: September 21, 2019

Accepted: October 23, 2019 Online Published: November 1, 2019

doi:10.5539/jel.v8n6p150

URL: https://doi.org/10.5539/jel.v8n6p150

\begin{abstract}
The Muslim minority in Thrace is a heterogeneous group of people regarding their cultural and linguistic identities. It consists of Muslims of Turkish origin who speak Turkish as their mother tongue, of Pomaks, who speak Pomak, and of Roma, who speak Romani. Their educational-linguistic situation is fraught with long-lasting problems, which are attributed to the inherent characteristics of 'Minority Education', a term used to describe a specific group of primary and secondary schools, situated exclusively in the area of Thrace, that operates under a special regime, as stipulated in legal instruments of international law and bilateral agreements, and can be attended only by Muslim minority children.

Extensive research over the years has shown that there are serious impediments in these students learning Greek as an L2, even after the implementation of the Project for Reform in the Education of Muslim Children (PEM) and the additional educational material that targeted this particular religious minority. The results show that most of these students do not achieve a language level of A2 in Greek and, thus, exhibit low school performance. Similar results have been recorded in research papers concerning learning English as a FL, which is a compulsory school subject, by Muslim minority students in both public and minority primary schools. These students also fail to achieve the foreign language attainment level set in the school curriculum.

The present paper seeks to outline the unchartered causes of this situation, delve into the language situation of Muslim students and suggest possible and viable solutions.
\end{abstract}

Keywords: minority education, bilingualism, trilingualism, second language learning (L2), foreign language teaching (FL)

\section{Definitions and Conceptual Framework}

It is important to clarify certain concepts such as L2, FL, bilingualism and trilingualism in relation to the Muslim group which is studied in the present paper before attempting any suggestions that will offer viable solutions to the previously-described language situation of these students.

\subsection{Second Language (L2) and Foreign Language (FL)}

Second Language (L2) is the language people learn after the acquisition of their mother tongue (Triarchi-Herrmann, 2000, p. 55; Halkopoulou, 2014, p. 27). The difference between second and foreign language is the setting and the condition in which the second language code is learnt as outlined in Table 1. 
Table 1. Difference between second and foreign language learning setting

\begin{tabular}{lll}
\hline Language learning setting (Note 1) & Second Language (L2) & Foreign Language (FL) \\
\hline Time & The acquisition of L1 has already progressed or has just been concluded \\
Place & In a language setting among native speakers & In a language setting where there is minimum or \\
& & no contact with native speakers \\
Reason & Present need to improve communication & Personal choice/interest or school subject that \\
& skills for everyday use & provides future qualifications
\end{tabular}

Both terms seem to be freely interchangeable in most research papers. The term L2 is usually used instead of FL to refer to all other languages learnt besides the mother tongue (Bella, 2011, p. 21).

\subsection{Individual and Societal Bilingualism/Trilingualism}

The term Individual bilingualism/trilingualism focuses on the individual; it includes the language development or behaviour on a personal level and refers to the language competence of the individual language user. Societal bilingualism/trilingualism focus on the social implications of the language situation of bilingual/trilingual people and their communication in a particular geographical area (Clyne, 1997, pp. 301-314; Damanakis-Skourtou, 2001, pp. 88-98). It refers to a situation where two or three different languages (abstand languages) are used in a particular speech community.

In the present paper the term trilingualism is used to highlight the fact that pomak and romani are constantly ignored as the mother tongues of a large part of Muslim students.

\section{Overview of the Current Situation}

\subsection{Population of the Muslim Minority in Thrace}

The Muslim minority in Thrace is the only explicitly recognized minority in Greece (Note 2) and it is a religious minority that resides in the area of Thrace in northern Greece (Kotsonis, 2015, p. 74; Nola, 2017, p. 75). It consists of three different groups, those of Turkish origin, who speak Turkish as their mother tongue, the Pomaks, who speak the pomak language (Adamou, 2012, pp. 7-8; Markou, 2002, pp. 43-46; Gkiouzelidis, 2018, pp. 4, 24) and Roma, who speak romani (Adamou, 2008; Adamou, 2012, p. 23; Gkiouzelidis, 2018, p. 6; Sella-Mazi, 2016, p. 36). Each of these groups has its own cultural traditions and quite separate speech communities, mainly in terms of their areas of residence.

\subsection{The Language Identity of Muslim Students in Minority Primary Education and Public Primary Education}

As already mentioned, the Muslim minority in Thrace is a religious minority consisting of three different cultural and language groups. Their common religious beliefs have, however, led the Greek state to treat them as a community that also shares a common language and linguistic background and ignored their different cultural traditions, their own self-identification (Note 3) and their distinct mother tongues which are linguistically unrelated. Romani is an oral language and pomak is of Slavic origin with significant similarities to the Slavic family of languages such as Bulgarian and is also an oral language though there have been attempts to develop its written form by the Pomaks. It should be noted that the Muslims of Turkish origin who speak Turkish as their mother-tongue are only $50 \%$ of the total Muslim minority community (Dimasi, Papastamatis, \& Stogios, 2014, pp. 14-15).

Furthermore, the languages used by the different groups are not in direct relation to their common religious identity or to their ethnic origin. The Turkish-speaking inhabitants of Thrace use a variety of the language which differs significantly from the formal language used in the neighbouring country of Turkey and is considered a separate dialect. The Roma, who number fewer members than the other two groups, speak romani which differs widely either from Turkish or the variety of Turkish spoken in Thrace (Sella-Mazi, 2016, p. 36). The Pomaks have their own very distinct mother tongue which is an east Bulgarian and south Slavic language variety with great geographical variation. It is only spoken and used by the particular speech community in the specific geographical area as their vernacular and is considered of pivotal importance for their identity and a point of reference of their cultural heritage (Sella-Mazi, 2016, p. 36) (Note 4). It should be noted that in terms of the ethnic origin and identity of the Pomaks there is a long-standing controversy between Greeks, Bulgarians and Turks, each one making different claims on both the language and ethnic origin of the Pomaks (Askouni, 2006, pp. 34-35; Empirikos et al., 2001, pp. 22-33; Sella-Mazi, 2001, pp. 195-196).

\subsection{Teaching L2 in Minority Primary Schools in Thrace}

Current minority education (Note 5) is bilingual (Lazaridou, 2017, p. 6). Students are taught the Turkish 
language as mother tongue and the Greek language as L2. Moreover, there is a dichotomy of the curriculum in minority primary education (Note 6) as students are taught religious education, maths physics and chemistry in Turkish and history, geography, studies of the environment and P.E. in Greek. At the same time, they are taught modern foreign languages, English as their first foreign language and either French or German as their second.

The Greek language is taught with no reference to the Cross Thematic Curriculum Framework for compulsory education. Instead, teachers use as a reference point the guidelines provided by the programme PEM (Note 7) and its teaching material which aims at teaching Greek as an L2 and which was compiled in 2000 (Huseyinoglu, 2012, p. 248).

Extensive research (Berdis, 2015; Bora, 2010; Theologou, 2017; Gkaintartzi \& Tsokalidou, 2011; Gkaintartzi, Kiliari, \& Tsokalidou, 2015; Gkiouzelidis, 2018; Huseyinoglu, 2012; Kaintatzi, 2017; Malamidis, 2008; Xanthopoulou, 2008; Sakonidis, 2017; Salim, 2017; Spathariotou, 2012; Simeonidis, 2014; Skourtou \& Kourti-Kazoulli, 2016) in the area has highlighted the following discrepancies and impediments.

A. on a practical level:

- lack of teachers' awareness and training

(1) in the area of bilingualism and its implications

(2) in the appropriate teaching approach to the educational material

(3) in the need to renew and renovate the educational content used for teaching the Greek language as an L2

B. on a theoretical-scientific level

- the Muslim minority is mistakenly considered a homogeneous Turkish-speaking group regarding the linguistic policy of central government (Skourtou \& Kourti-Kazoulli, 2016, p. 15; Gkiouzelidis, 2018, p. 24).

- the educational material used lacks provision for all those Muslim students (Pomaks, Rom $\alpha$ ) whose mother tongue is not Turkish and they are forced to learn the Turkish language as an L2 and the Greek language as an L3 (Gkiouzelidis, 2018, pp. 25, 46-47; Kotsonis, 2015, pp. 83-84).

- the low level attainment in the Greek language which is observed to almost all Muslims students that finish primary education despite the exclusive use of the material designed by the proponents of the programme PEM for the last 20 years (Kaitatzi, 2017; Kaxira et al., 2011, pp. 106-107; Kotsonis, 2015, pp. 78, 175; Lazaridou, 2017, p. 115; Sakonidis, 2017, pp. 42-45).

\subsection{Teaching L2 to Muslim Students in the Public Primary Schools in Thrace}

Teaching Greek to the children of the Muslim minority in the public primary schools has been fraught with systemic impediments (Kalliga, 2016, pp. 40-41, 112; Kotsonis, 2015, pp. 79-83) as far as their learning of the language is concerned since:

- the current curricula used in public primary schools set as a prerequisite that the Greek language is the pupils' mother tongue. As a result, they employ teaching practices and methods accordingly

- Muslim students are taught with the same textbooks as those used for the students who speak Greek as their mother tongue

- in terms of the educational policy adopted there is no special provisions for bilingualism which is the main end-result anticipated for these students

- teachers are not trained to use differentiated teaching methods in order to cater for the deficiencies observed in the curriculum and the textbooks regarding potential bilingual students.

It should be noted, however, a constant rise in the number of Muslim children that attend public primary schools (Mitsiou, 2010, p. 82; Kotsonis, 2015, pp. 90-91). In 1999-2000 the number of Muslim children registered in public primary schools was 100 which is rather small compared to the year 2004-2005 when they reached the 201, followed by the year 2005-2006 and a total number of 343. In 2007-2008 the number of Muslim students that attended public primary schools, 480 students, was higher than that of the students that opted for schools that provided minority education, 465 in total (Notaras, 2008). More recent evidence show that these numbers continue to increase. In 2015-2016, a total of 1867 Muslim children attended public primary schools, 654 in Xanthi, 602 in Rodopi and 611 in Evros (Note 8).

\subsection{Teaching FL in Minority Primary Schools in Thrace}

The English language is taught as a mandatory foreign language in all public schools and is also part of the curriculum in minority primary schools. However, minority primary schools that are located in rural areas, far 
from the metropolitan cities and number only a few students, are deprived of such a privilege as there is a lack of English language teachers. It is estimated that English is not taught in 2.789 minority schools which are the 45\% of the total number of primary minority schools (Dimasi, 2014, pp. 14-15). Therefore, students there finish primary school without having been taught English as part of their curriculum, at least in the lower grades.

In minority primary schools English is taught as a FL to Muslim students who are:

- of Turkish origin and speak Turkish as their mother tongue and Greek as a L2

- Pomaks, they speak pomak as their mother tongue but are taught Turkish as a mother tongue at school and Greek as a L2

- Roma, they speak romani as their mother tongue but are taught Turkish as a mother tongue at school and Greek as a L2.

Thus, in minority primary schools, students are taught Turkish, Greek and English. As already mentioned, half of these students do not speak any of these languages and use a different language to communicate with their own speech community. Their education is referred to as bilingual, however, it is built on the false premise that all Muslim students share the same mother tongue. For these students, language learning and especially foreign language learning proves to be a difficult and even impossible task, one that is fraught with inherent impediments that undermine their language and school performance.

\subsection{Teaching FL in Public Primary Schools with Muslim Students in Thrace.}

As already mentioned, the English language is taught as a mandatory foreign language in all public primary schools (Dendrinos et al., 2013, p. 72) without there being any difference in the objectives outlined in the Cross Thematic Curriculum Framework for compulsory education and the new Integrated Foreign Languages Curriculum between public and minority primary schools.

According to the Cross Thematic Curriculum Framework for compulsory education, English as a FL is taught with reference to the Greek language which is considered students' mother tongue. In particular, in the specific goals outlined there, it is emphasized that students have to develop 'abilities that will allow them to use their mother tongue and the foreign language at the same time' (2003, p. 355). This particular goal is further elaborated in various objectives which determine that students have 'to convey in Greek the gist of an English oral or written text', to discuss or produce a brief written text in the FL based on a written or oral text in L1 or vice versa, 'to read similar texts one in Greek and the other in English and identify parallel or conflicting messages' (2003, p. 377). In this frame, there are several suggested activities such as translations of English and Greek texts or the hosting of a literary event where excerpts from novels by Greek or American authors will be read (2003, p. 377).

The new Integrated Foreign Languages Curriculum, which is also used in compulsory education, and the English school textbooks presuppose knowledge of the Greek language as the students' mother tongue and take into consideration the principal methodology and the differences between L1/FL regarding structure, vocabulary and other aspects of the language. For instance, the mediation (Note 9) activities included in the textbooks both for oral and written production are in Greek (Note 10) and there are several other instances where Greek is referred to as the students' mother tongue.

It seems, therefore, that in the case of Muslim students, who attend public primary schools, they have to learn English as part of the curriculum and:

- are taught the English language alongside with the rest of the students who have Greek as their mother tongue

- some of them are of Turkish origin and speak Turkish as their mother tongue

- some of them are Pomaks and speak pomak as their mother tongue

- some of them are Rom and speak romani as their mother tongue

These students are taught English as their first foreign language on the premise that Greek is their mother tongue.

\section{Discussion}

There are ways to improve the current situation and help Muslim minority students improve their second and foreign language literacy.

Initially, the terms bilingualism and trilingualism need to be clarified and redefined in relation to the different language groups that belong to the Muslim minority in Thrace and the extent of multilingualism encountered 
within this group. The teaching methodology and material used in minority and public schools should be reconsidered and re-designed in relation to the aforementioned issues of trilingualism and bilingualism Muslim students face and with respect to their mother tongues and cultural backgrounds. Furthermore, in the case of public schools, Muslim students can be assisted with learning material which is designed for bilingual students and additional teaching hours that would help improve their L2 and FL level of proficiency.

On a broader level, there need to be a shift in educational language policy in relation to Muslim minority students and their learning of Greek as a second language and English as a foreign language. Issues of multilingualism, of appropriate teaching material and/or textbooks, of teaching practices and approaches as well as of sufficiently-qualified educators need to be tackled on the level of central policy towards the minority students in Thrace. The extent to which the special language needs these students have, as a result of their multilingualism and of their language identities, are taken into consideration is a matter of educational policy, its affordances and perspectives as well as its long-term goals and aspirations.

In the case of Muslim students who either attend minority or public schools, learning English as a FL is contingent upon the teaching material used. That includes textbooks and the curriculum. It is also heavily depended on the teaching methodology adopted by the English language teachers, their scientific knowledge and training regarding teaching a FL to bilingual and/or trilingual students.

Either the current English language textbooks used should be revised taking into consideration the particular learning needs of the bilingual students or supplementary material adapted to their needs should be made available. Activities and tasks included in the textbooks need to be revisited regarding all four skills, oral and written comprehension and production as well as their communicative context within the frame of bilingualism/trilingualism and with reference to the particular students. The teaching strategies implemented and the material used to achieve foreign language literacy determine the learning outcome observed in minority students.

The views of Greek and English language teachers in relation to the textbooks used in both public and minority schools for either L2 or FL learning should be taken into consideration. Teachers' views, though considered a 'messy construct' (Pajares, 1992, p. 309) are still indicative of the decisions they make during their teaching process (Kagan, 1992, p. 66) and that is a major reason why their views should be considered when designing and implementing educational policies. What is more, 'bringing the teachers' voices and practices to the attention of researchers, policy makers', reveals the importance of their roles in the education of Muslim students (Niyozov \& Pluim, 2009, p. 637). This is even more important when their views map the situation regarding the textbooks used and the teaching strategies implemented in minority language education. Teachers' views may also help clarify the reasons for the low English language level observed among Muslim students who attend either public or minority schools. They can provide the necessary feedback for both the language educational policy followed, including English as the mandatory foreign language, in minority and public education in relation to Muslim students. Also, teachers may provide the necessary insight in why the designated textbooks, the proposed methodology and the formal curriculum have not managed to tackle with the problem of the consistent low foreign language level among Muslim students, no matter whether they attend public or minority schools. Language teachers' views can help shape educational policy regarding minority education and foreign language learning towards facilitating minority students when learning Greek as a second language and English as a foreign language.

Moreover, it is of vital importance to 'educate the educators'. There should be special provision regarding the training of language teachers who are assigned classes with minority students. Teachers need to be provided with the proper scientific and methodological scaffolding in order to overcome especially the challenges they face when teaching English to minority bilingual or trilingual students, whose mother-tongue is not Greek and whose language attainment regarding the Greek language is - as previously mentioned - quite low. The fact that Greek is often used in FL activities such as the mediation activities, poses additional impediments to teaching minority students.

It should be additionally noted that the practice of having Muslim minority students attend FL classrooms in mixed ability classrooms needs to be revisited and remodelled. Taking into consideration that these students experience impediments to their learning of English that relate specifically to issues of bilingualism/trilingualism and their different and differing mother-tongues it is necessary that they are provided with further support and ad hoc educational intervention within the classroom setting as well as additional tutoring within the school setting. In this way, their exiting or, in some cases, presupposed bi/trilingual language identities will not hinder their learning of English as a foreign language. 


\section{References}

Adamou, E. (2008). Sur les traces d' une dégrammaticalisation: le médiatif en Pomaque (Grèce), Revue des études slaves. 79(1/2), Communications de la délégation franqaise au XIVe Congrès international des slavistes, 177-189. https://doi.org/10.3406/slave.2008.7133

Adamou, E. (2012). Social Networks in Greek Thrace: Language Shift and Language Maintenance. In J. Lindstedt \& M. Wahlström (Eds.), Slavica Helsingiensia 41 (Balkan Encounters: Old and New Identities in South-Eastern Europe, pp. 7-32). Helsinki: Department of Modern Languages, University of Helsinki. Retrieved from http://www.helsinki.fi/slavicahelsingiensia/preview/sh41/pdf/1.pdf

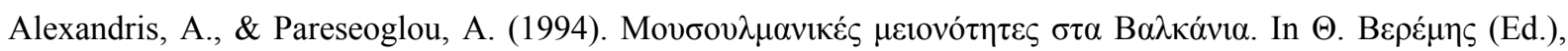

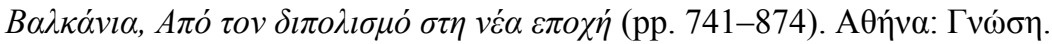

Askouni, N. (2006). The education of the minority in Thrace: from the margin to the prospect of social integration. Athens: Alexandria.

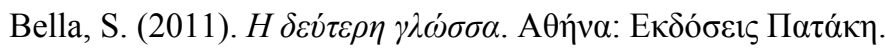

Berdis, A. (2015). Access to Higher Education. A study of the social, educational and institutional dimensions of tertiary education. Problems and policies from a comparative-historical and empirical perspective. Retrieved from http://repository.edulll.gr/edull1/retrieve/11161/3112Paradoteo3.pdf

Bora, I. (2010). The values taught in the Greek language textbooks of minority primary schools. Master's thesis, Department of Language, Literature and Civilization of the Black Sea Countries, Democritus University of Thrace, Greece.

Clyne, M. (1997). Multilingualism. In F. Coulmas (Ed.), The Handbook of Sociolinguistics (pp. 301-314). Oxford/UK and Malden/USA: Blackwell. https://doi.org/10.1002/9781405166256.ch18

Cross Thematic Curriculum Framework. (2003). Retrieved from http://www.pi-schools.gr/programs/depps/

Cross thematic curriculum framework for compulsory education. (2003). Retrieved from http://www.pi-schools.gr/download/ programs/depps/english/14th.pdf

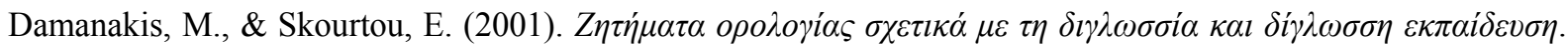

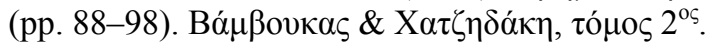

Dendrinos, B. (2006). Mediation in Communication, Language Teaching and Testing. Journal of Applied Linguistics, 22, 9-35.

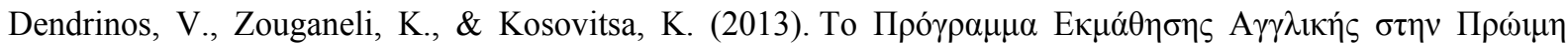

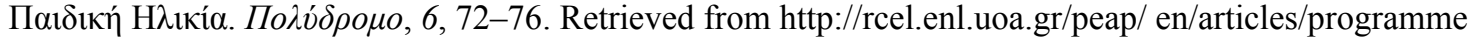

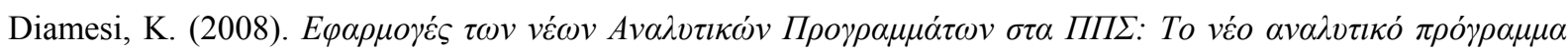

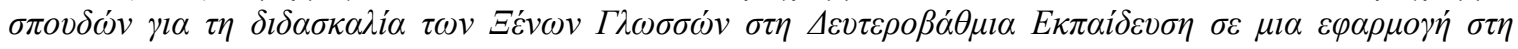

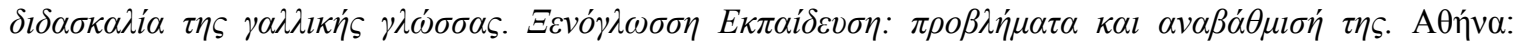
KE.ME.TE. Retrieved from http://3dim-evosm.web.auth. gr/conference/pp.403-409.pdf

Dimasi, M., Papastamatis, A., \& Stogios, I. (2014). The Muslim minority in Thrace: Educational issues. Mare Ponticum, 4(4). Retrieved from http://mareponticum.bscc.duth.gr/indexhtmfiles/Dimasi4.pdf

Empirikos, L., Ioannou, A., Karatzola, E., Baltsiotis, L., Beis, S., Tsitselikis, K., \& Christopoulos, D. (eds.)

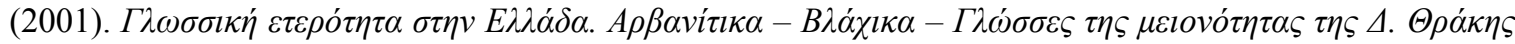

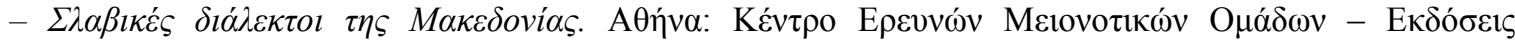
$\mathrm{A} \lambda \varepsilon \xi \dot{\alpha} \alpha \delta \rho \varepsilon \imath \alpha$.

Gkaintartzi, A., Kiliari, A., \& Tsokalidou, R. (2015). 'Invisible' Bilingualism - 'Invisible' Language Ideologies: Greek Teachers' Attitudes towards Immigrant Pupils' Heritage Languages. International Journal of Bilingual Education and Bilingualism, 18(1), 60-72. https://doi.org/10.1080/13670050.2013.877418

Gkaintartzi, A., \& Tsokalidou, R. (2011). 'She is a very good child but she doesn't speak': The invisibility of children's bilingualism and teacher ideology. Journal of Pragmatics, 43, 588-601. https://doi.org/10.1016/j.pragma.2010.09.014

Gkiouzelidis, T. (2018). The Pomaks of Rodopi: The Influence of Local Media on Pomak Identity and Social Integration. Master's thesis, Aristotle University of Thessaloniki, Greece. Retrieved from http://ikee.lib.auth.gr/record/298561/files/GRI-2018-21842.pdf 
Halkopoulou, C. (2014). The sociolinguistic and educational factors that influence diglossia. A comparative study case of minority and repatriated students from countries of the former USSR in Rodopi. Master's thesis, Department of Language, Literature and Civilization of the Black Sea Countries, Democritus University of Thrace, Greece.

Huseyinoglu, A. (2012). The Development of Minority Education at the South-easternmost Corner of the EU: The Case of Muslim Turks in Western Thrace, Greece. Doctoral dissertation, University of Sussex. Retrieved from http://sro.sussex.ac.uk/

$\begin{array}{lllll}\text { Integrated } & \text { Foreign } & \text { Languages } & \text { Curriculum. } & \text { (2016). Retrieved }\end{array}$ http://rcel.enl.uoa.gr/xenesglosses/docs/EPScontent.pdf

Kagan, D. (1992). Implications of research on teacher belief. Educational Psychologist, 27(1), 65-90. https://doi.org/10.1207/s15326985ep2701_6

Kaintatzi, T. (2017). Muslim minority teachers' views concerning the inclusion of Muslim pupils and non-Muslim pupils in public elementary schools in Thrace. Master's thesis, Hellenic Open University. Retrieved from https://apothesis.eap.gr/handle/repo/35363

Kalliga, D. (2016). Minority education in Greece: The voices of the teachers working in minority primary schools in Xanthi. Master's thesis, University of Western Macedonia, Greece.

Kaxira, P., Kaplani, E., Makrigiannis, S., \& Poutahidis, Y. (2011). Educating linguistic minorities: research in the Muslim Minority of Thrace. 6th International Conference in Open \& Distance Learning - November 2011, Loutraki, Greece. Retrieved from https://eproceedings.epublishing.ekt.gr/index.php/openedu/article/view/664/676

Kotsonis, K. (2015). Language policies of Muslim parents who sent their children in the public primary school. Master's thesis, School of Education, University of Crete, Greece. Retrieved from https://elocus.lib.uoc.gr/dlib/a/9/c/metadata-dlib-1525352162-474169-6029.tkl

Lazaridou M. (2017). Educational trajectories of students from the Muslim minority of Thrace. Master's thesis, Aristotle University of Thessaloniki, Greece. Retrieved from http://ikee.lib.auth.gr/record/296153/files/GRI-2018-21022.pdf

Markou, K. (2002). Les Pomaques de Thrace grecque et leurs choix langagiers. Études balkaniques [en ligne], mis en ligne le 09 août 2008, consulté le 13 juillet 2015. Retrieved from http://etudesbalkaniques.revues.org/129

Ministry of Education, Research and Religion. (2013). Primary education minority schools. Retrieved from https://www.pdeamth.gr/ index.php/2013-06-24-13-41-40/meionotika-sxoleia-amth

Ministry of Education, Research and Religion. (2013a). Secondary education minority schools. Retrieved from https://www.pdeamth.gr/index.php/2013-06-24-13-41-40/meionotikasxoleia-de-amth

Mitsiou, I. (2010). Minority education in W. Thrace: social and educational challenges and perspectives for access to secondary education and universities of turkish speakers and Roma people. Doctoral dissertation, Panteion University of Social and Political Sciences, Greece.

Niyozov, S., \& Pluim, G. (2009). Teachers' Perspectives on the Education of Muslim Students: A Missing Voice in Muslim Education Research. Curriculum Inquiry, 39(5), 637-677. https://doi.org/10.1111/j.1467-873X.2009.00463.x

Nola, A. (2017). Freedom of religion in Greece and islam: challenges and perspectives in a changing environment. Master's thesis Aristotle University of Thessaloniki, Greece. Retrieved from http://ikee.lib.auth.gr/record/ 288863/files/GRI-2017-19122.pdf

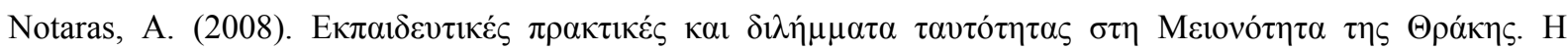

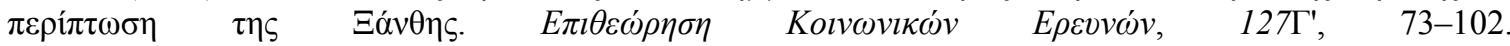
https://doi.org/10.12681/grsr.9878

Pajares, M. F. (1992). Teachers' beliefs and educational research: Cleaning up a messy construct. Review of Educational Research, 62, 307-332. https://doi.org/10.3102/00346543062003307

Project for Reform in the Education of Muslim Children (PEM). Retrieved from https://museduc.gr/en/

Regional Directorate of Primary and Secondary Education of Thrace. Retrieved from https://www.pdeamth.gr/index.php/2013-06-24-13-41-40/meionotika-sxoleia-amth 


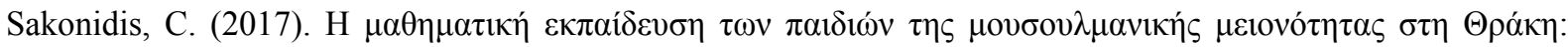

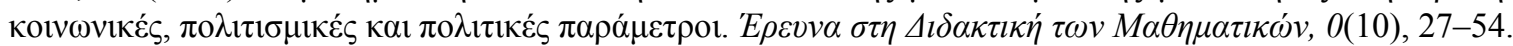
https://doi.org/10.12681/enedim.15217

Salim, O. (2017). Cultural elements in language textbooks of the Greek programme for the $6^{\text {th }}$ grade of minority primary schools. Their use in the frame of the pedagogy of multiliteracies. Master's thesis, Department of Language, Literature and Civilization of the Black Sea Countries, Democritus University of Thrace, Greece.

Sella-Mazi, E. (1992). La minorité turcophone musulmane du nord-est de la Grèce et les dernières evolutions politiques dans les Balkans. Plurilinguismes, 4, 203-231. Centre d'études et de Recherches en Planification Linguistique.

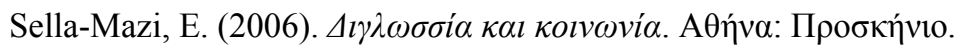

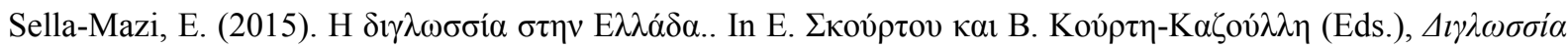

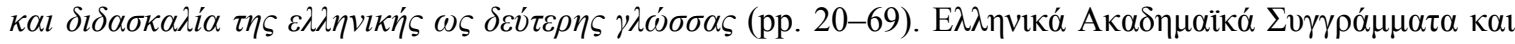

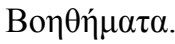

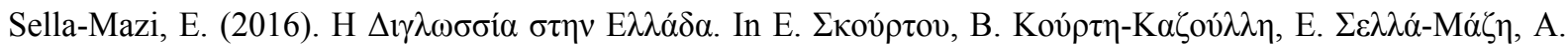

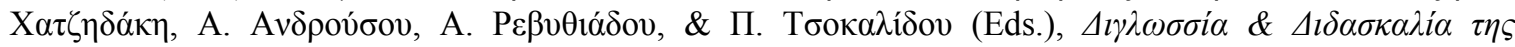

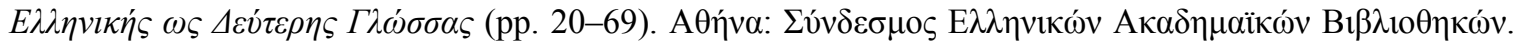
Retrieved from http://hdl.handle.net/11419/6345

Simeonidis, V. (2014). The legal framework of minority education. Discrepancies, problems and concerns. A critical view. Master's thesis, Department of Language, Literature and Civilization of the Black Sea Countries, Democritus University of Thrace, Greece.

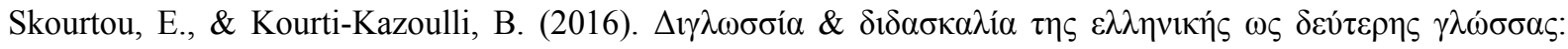

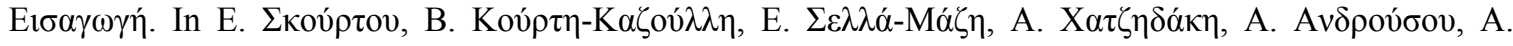

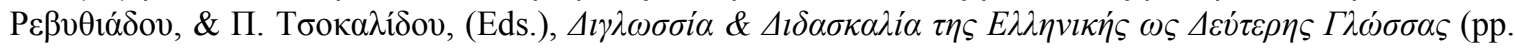

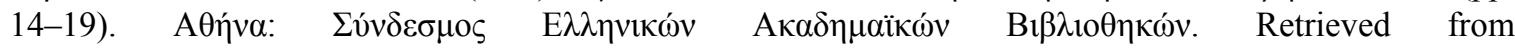
http://hdl.handle.net/11419/6347

Spathariotou, S. (2012). English language teaching methodology in the textbooks used in primary minority education. Master's thesis, Department of Language, Literature and Civilization of the Black Sea Countries, Democritus University of Thrace, Greece.

Stavros, S. (1995). The legal status of Minorities in Greece today: The adequacy of their protection in the light of current human rights perceptions. Journal of Modern Greek Studies, 13(1), 1-33.

Theologou, S. (2017). Multimodality and visual literacy in high school textbooks for teaching English: teachers' views on their use for the Muslim minority students in Thrace. Doctoral dissertation, Democritus University of Thrace, Greece. Retrieved from https://phdtheses.ekt.gr/eadd/handle/ 10442/39855

Treaty of Lausanne. (1923). http://hellas0099.com/TREATIES/LAUSANNE\%20 TREATY.pdf

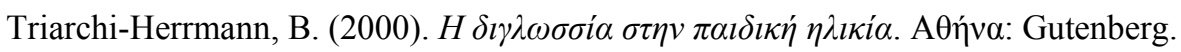

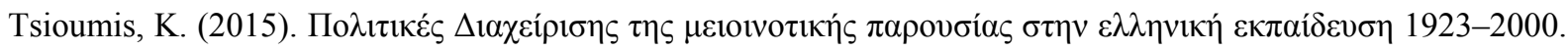

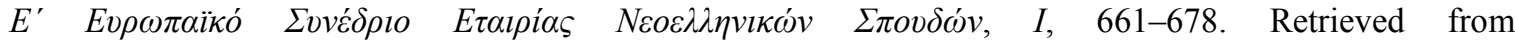
https://www.eens.org/EENS_congresses/2014/tsioumis_kostis.pdf

Xanthopoulou, E. (2008). Language education of the Muslim minority in Greece in primary schools: Legal framework, school textbooks, curricula and timetables. Master's thesis, Department of Language, Literature and Civilization of the Black Sea Countries, Democritus University of Thrace, Greece.

\section{Notes}

Note 1. The verb 'acquire' is most frequently used for L2 and the verb 'learn' for FL respectively (Triarchi-Herrmann, 2000, p. 55; Halkopoulou, 2014, p. 27).

Note 2. The official Greek text of the Treaty of Lausanne (1923) refers to 'Muslim minorities' in article 45 and there is no mention of any ethnic or other minority. There is no specification of a particular minority language but there is a general stipulation that 'whichever language is protected, not only as the language used for communication but also for education' (articles 39, 40, 41). Source: http://hellas0099.com/TREATIES/LAUSANNE\%20 TREATY.pdf. 
However, the pomak and the romani languages have never been taught, probably because both are oral languages with no written form on a scientific level and are characterised by significant dialectical variety (Sella-Mazi, 2015, p. 42).

What is more the Turkish language has dominated the Muslim minority education, particularly because it has been ardently promoted and fostered by the Turkish government, who has managed, with the Protocols, which were signed with the Greek government in 1951 and 1968, to impose Turkish as the only language used within the Muslim minority and taught in minority education (Alexandris \& Paresoglou, 1994, p. 751; Sella-Mazi, 2015, p. 38; Stavros, 1995, pp. 10-23)

Note 3. The Pomaks are particularly conscious of their ethnic origin which they consider distinct and distinguish it from the other groups that form the Muslim minority. This is quite evident in their folk songs, one of which has the following verse: 'I'm not a Turk or a Slav or a Janissary, I was born a Pomak, a Thracian gladiator'. Source: http://zagalisa.gr/.

Note 4. There has been a substantial effort on the part of the Pomaks to learn their mother-tongue -which is only a spoken language- to use it for written communication as well. For example, there is a newspaper, 'Zagalisa' written in pomak (http://zagalisa.gr/), and there have been reference books such as a dictionary and a grammar book of the pomak language (Source: https://xanthinet.gr/index.php/home/item/3508-neo-morfologiko-leksiko-tis-pomakikis). It should be noted that the dictionary is a pomak-Greek and Greek-pomak dictionary with no reference to the Turkish language and the word transcription uses the Greek alphabet (Source: http://zagalisa.gr/content/ellino-pomakiko-leksiko-line).

Note 5. Minority primary schools follow a supposedly bilingual educational programme where Turkish and Greek are not only school subjects but also languages of instruction.

Note 6. Minority education refers to a group of schools mainly in primary education and less in secondary education that follow a different educational policy which is found only in the area of Thrace and is available exclusively to the children of the Muslim minority (Simeonidis, 2014, p. 30). The curriculum applied in minority education was published in 1979 and it has not been revised since. In the beginning of the 1990s the English language has been introduced to a limited number of minority primary schools, mainly those in the city centres.

Note 7. The Project for Reform in the Education of Muslim Children (PEM) is funded by the European Social Fund and is supervised by the Ministry of Education, Research and Religious Affairs. It aims at 'improving and enhancing the education they receive, with emphasis on their achieving fluency in Greek'. The program is implemented and organised by the KESPEMs (the Support Centres of the Project, operating in urban and rural areas of Thrace). These Centres offer classes for primary-school kids that aim at improving their command of Greek. They also offer 'tutoring support for secondary and high school pupils in the Greek Language, Literature, Mathematics and Natural sciences courses that aim at improving their level in the Greek language and enhance educational success'. Source: https://museduc.gr/en/

Note 8. Source: Regional Directorate of Primary and Secondary Education of Thrace, https://www.pdeamth.gr/index.php/2013-06-24-13-41-40/meionotika-sxoleia-amth and https://www.newsbeast.gr/greece/ekpaideusi/arthro/753332/arithmos-mathiton-kai-ekpaideutikon-sta-meionotika -sholeia

Note 9. In a mediation activity, students are required to selectively extract information, ideas and meanings from a source text in Greek and use them selectively to produce their own text, in the target language (Dendrinos, 2006, pp. 22-23). The text type and the communicative purpose of the target text may be different from that of the source text (Dendrinos, 2006, pp. 24-25), thus, students have to thoroughly understand the communicative context in order to act as mediators.

Note 10. Integrated Foreign Languages Curriculum (2016, pp. 18-22)

\section{Copyrights}

Copyright for this article is retained by the author, with first publication rights granted to the journal.

This is an open-access article distributed under the terms and conditions of the Creative Commons Attribution license (http://creativecommons.org/licenses/by/4.0/). 